\title{
CLINICAL AND HEALTH PSYCHOLOGY
}

\section{Cultural-psychological and clinical perspectives of research on phenomena of subjective uncertainty and ambiguity}

\author{
Elena T. Sokolova \\ Lomonosov Moscow State University, Moscow, Russia
}

\begin{abstract}
The article analyzes certain socio-cultural and personal predispositions, which determine the modern diversity of subjective uncertainty and ambiguity manifestations. It stresses that for the creation of 'realistic' clinical psychology (in terms of A.R. Luria) one needs to retrace the relations between the resourceful and the psychopathological aspects of the ambiguity phenomenon and the cultural environment with its destructive ideals and mythologems, manipulative media-technologies and all-pervading idea of 'deconstruction'. Methods for modeling the experiences of ambiguity in experimental settings, in pathopsychological examination and in projective psychological diagnostics are put in comparison. The arguments are adduced for the interpretation of deficient manifestations of subjective uncertainty as a criterion for diagnostics of the severity of personality disorder.
\end{abstract}

Keywords: subjective uncertainty (ambiguity) phenomena, socio-cultural, personal and clinical predispositions, experimental modeling, projective paradigm, individual styles of ambiguity transformations, borderline personality organization and psychopathology.

One of the main consequences of the cultural-historical approach of L.S. Vygotsky, A.R. Luria and A.N. Leontiev in psychology was instigation of studies in psychic structure on the basis of social and cultural conditions, requirements and framework of the practical objective activity. As A.R. Luria showed in his early and widely known work Cultural differences and intellectual activity, cognitive activity, which results from direct practical experience, and activity, which is mediated by 'logical codes', have different structure and efficiency depending on conditions and objective content of the cognitive task (Luria, 2001). The problems were formulated, which determined the trend of theoretical and experimental research in Russian psychology for the years to come: By virtue of which psychological mechanisms does the cultural situation change the structure and the organization of cognitive activity? What are the particular psychological mechanisms and the laws of interiorization process in norm and pathology? As it is known, the studies of L.S. 
Vygotsky's school had led to the articulation of an array of fundamental theoretic and methodological guidelines about the systemic structure of consciousness, its sign-symbolic mediation, about the structure and the functioning of 'common' and 'scientific' concepts, about age-specific dynamics of the higher psychic functions and their organization, about pathological development of personality.

The cultural-historical paradigm, which was elaborated by the school of L.S. Vygotsky, points out social conditions, critical situations and the role of communication as the mediators of normal and pathological psychic development and thus sets the new theoretical model of the psychic, the methodology of experimentation in psychology as a whole and in clinical psychology in particular (Vygotsky, 1982). Special A.R. Luria's interest kindled the research of affective conflicts and 'complexes' with objective methods. Thus, due to the widely used plethysmograph he managed to measure the semantic structure of consciousness and later educed some conditions that influence the development, the content and the change of the breadth of semantic systems. He also generated such modeling of changes in experimental situation as variation of instructions, of stimulus material, of inner emotional states, of motivations and attitudes of the subject (Luria, 2003a). Therefore, he proved the dependence of semantic content of the psychic (including currently not represented in consciousness) on the level of cultural development, ethnical conditions, professional training and on the specifics of cultural tools used as mediators.

In his contemplations about the future of the so-called 'realistic psychology' A.R. Luria emphasized the importance of studying macro- and microsocial influences (class-specific and political biases, religiousness, group memberships etc.), which formulate substantial, structural and functional characteristics of individual mental life: “...in real human cognition we always find an array of alterations and 'distortions', which depend directly on social environment” (Luria, 2003b, p. 324). He also claimed that psychology, which disengages itself completely from particular circumstances of individual life, risks becoming a dogma, a scheme, a fiction, and thus the 'realistic psychology' should tend to the synthesis of nomothetic and ideographic principles of research (Ibid, p. 314) and ideally to renounce the positivistic (purely artificial, 'sterile') model of experimentation; it should take into account the role of individual biographies and conditions of development, particular social situations and communicative contexts both in past experience of a subject and in modeled here and now conditions of clinical survey and communication with psychologist.

For clinical psychologists the relations of contemporary culture (philosophy, art, cinematograph, styles of life), its destructive ideals and mythologems, manipulative media-technologies and all-pervasive idea of 'deconstruction' with various facets of socio-cultural phenomenon of subjective uncertainty is more or less obvious. In contemporary society the processes of bifurcation (intensification of uncertainty, unpredictability and chaos, in consequences of which anything may happen) appear in all spheres of natural and cultural, technogenic and personal surroundings. For a person the world becomes more controversial, unpredictable and uncontrollable.

One receives a complex and comprehensive block of tasks, which activates all levels of self-regulation in interaction with 'outer' social environment and intrapsy- 
chic mental space. Our contemporary has an acute sense of catastrophe, instability, uncertainty in the face of the present and the future. No less striking socio-psychological phenomenon is the fear of the social and cultural Other, of the one who does not fit into strict framework of ordinary and familiar, which, to our opinion, is tightly connected to intolerance for ambiguity. These are the roots and the mechanisms of intolerance in its most broad manifestation - ethnic, religious or any other intolerance, including intolerance for one's own inner self. The acute sense of lack of authenticity, self-discipline, inner coherence, orderliness, the feeling of emotional instability and the void of meaning are the essential phenomenology of personality disorders.

The meta-analysis of studies of defects of perception and self-perception, selfconsciousness, self-image and image of the Other draws us to the conclusion that the problem of subjective intolerance for ambiguity is tightly bound to some fundamental problems of clinical psychology - and not only with them. From the viewpoint of contemporary sociologists and culturologists, ambiguity in many of its socio-cultural manifestations is the spirit of the postmodern age (Bauman, 2002), the constitutive factor of the taken as a norm vagueness and fluidity of individual identity, moral relativism, unbelief and devaluation of interpersonal relations. All in all, postmodern sociologists tend to describe social processes clinically in terms of splitting, diffusion, fragmentation of self-identity, escalation of the problems of dependency-individuation in relations with society, which in some sense blurs the borders of uncertainty of social-objective environment and its subjective experience (Bauman, 2002; Beck, 2000). The powerlessness, the inefficiency, the chaotic actions and the terror of complete freedom are, according to Z. Bauman, the symptoms of this postmodern illness, which affects personality in its attempts of acquiring 'one's own face. The well-known philosopher and culturologist M. Epstein echoes these speculations on illness of personality, its social origins and consequences for the future of our country, and constructs something like the generalized psychopathological syndrome of social macromutations, marking out of the syndromal factors the degeneration of the population, the frailty of the state borders and the rupture of the Federation, the all-pervasive corruption and criminalization, cynicism and indifference of the main part of citizens. But yet the future is not predetermined by the aggravating 'symptoms' of this social illness. The author describes the conditions of the contemporary Russian society with the original oxymoron "hopeful ugliness', meaning that the imbalance of the current historical moment simultaneously holds two antagonistic outcomes: either the collapse of the whole social order, or its revival from the 'sprouts of hope', anomalous from the position of the developed postindustrial Western societies, but specific for Russia (Epstein, 2011). Thus, it is hard to escape the conclusion that the situation of uncertainty per se is not necessarily the destructive factor of development, it does not univocally predetermine its result, but it contains the potential for new creative possibilities as well. "The uncertainty of surroundings, which demands variability of behavior," claims V.P. Zinchenko, "is the basis of freedom and creativity" (Zinchenko, 2007, p. 17). T.V. Kornilova, who also analyzed the problem of uncertainty, came to the conclusion that "tolerance for ambiguity, openness and indefinite regulative profiles of any choice for voluntary and self-determined actions are the main conditions of active personal position in contemporary world" (Kornilova, 2010). 
It is absolutely clear that in conditions of the socio-cultural pressing the uncertainty and the ambiguity of the organizational principles of social interactions coupled with the appeal of manipulative and machiavellian technologies as the tools of governance and usurpation of power by a certain part of society hampers seriously the possibilities of personal choice. The pressure of irrationally heightened social demands of the autocratic authorities is especially unbearable and stress-producing for people with excessive vulnerability and frailty of self-identity, with marked characteristics of psychological dependency, deficient individuality and cognitive simplicity, which are indicative for the borderline personality organization (Sokolova, 1989,2005 , 2009). From our point of view, on the basis of the 3 criteria (specifics of the projected content of anxiety, means of psychological defense and state of self-identity) it is possible to mark out at least 5 typical experiences of subjective uncertainty, which is caused partly by the inability of a person to manage the chaos of social and cultural ambiguity that characterizes the depth of the personality disorder, and partly by its resourceful capacities.

1. The first type is colored - or even flooded - by the overpowering negative affect, the core of which consists of the intolerable persecutory anxiety. Here the share of subjective uncertainty is the highest: the obscurity, the blur, the shapelessness, the boundlessness, the incoherence call forth the paranoiac fantastic representations of alienation, hostility, splitting of inner and outer 'Other', which threaten the psychological survival and the integrity of the Self.

2. The second type is also connected with the negative spectrum of emotional states, but here somewhat different phenomenology dominates: ambiguity, ambivalence, polysemanticity, unpredictability, inconsistency, entanglement, complexity. The fear of novelty leads to the preference of simplicity, order, commonness, routine, narrow-mindedness and predictability as the defenses from the looming catastrophe of the new, unforeseeable future and the 'undeveloped fields of the unknown', of the feelings of shock, perplexity, agoraphobia and panic in the face of loss of self-control and selfconstancy.

3. The third type is characterized by the complete intolerance of uncertainty as a situation without an access to the inner resources and the resulting utmost dependence from social environment, the renouncing of the own system of norms, the preference for personal and social conformity, the complete submission to authority, regime, power, the alignment of the own self, the merging with situation and becoming a chameleon as a character in the Woody Allen's movie Zelig.

4. The fourth type of experiencing uncertainty is the manic projection of 'intoxication' with transgression and chaos, with the lack of all kinds of limits, of any restrictive norms and rules, with the preference for narcissistically perfectionistic all-accessibility and all-permissiveness.

5. To the last type, which is much less presented in pathology, pertain the positively colored experiences: curiosity, exploratory above-situational activity, games of imagination, generation of new meanings, joy, excitement as the 
causes of pleasure from investigations and insights, which lead to creative and meaningful transformation of uncertain situations.

It is surprising that clinical psychology still does not give enough attention to the studies of subjective uncertainty. In the mean time, for more than 50 years cognitive and social psychology have been successfully developing and using various methods of creating experimental uncertainty: misfocusing of stimulus and conditions of its presentation, polysemantisity and ambiguity, emotional deprivation and variation of motivations, communicative and group contexts, etc. Due to the new research models, which are based on controlling the structure of objective and social environment and adopted from projective psychology, the role of attitudes, activity, prejudice, subjective stability in resistance to field forces, individual, age-specific and cultural differences in cognitive strategies (or in cognitive-affective styles) had been studied (Bruner et al., 1971; Rotenberg (Sokolova) 1971, 1976, 1980, 2005, 2009, 2011; Holodnaya, 1998; Auerbach, Blatt 1996; Blatt, Lerner 1983; Adorno et al. 1950; Hogg 2007; Witkin et al., 1954, 1981). Situational and personal determinants of successful coping with uncertainty during adaptation to changing 'cultural contexts' in complex or unfamiliar social environment (Belinskaya, 2007, 2009), links between tolerance for ambiguity and intellectual resources of personality, intellectual self-esteem (Kornilova, 2010) have been also considered.

The contemporary studies of 'diffused' and narcissistically-grandiose identity (including research on effectiveness of psychotherapy) show a great number of implicit indications of pathogenic role of uncertain social codes and rules, domestic scenarios and communicative styles, cultural ideals and moral criteria. In conditions of uncertainty people with 'fragile' borderline personal organization are especially prone to the loss of inner consistency and coherence of the self and the loss of time-perspective. Their diffused self-identity easily loses its essential qualities of historicity, dynamism, stability and authenticity under the pressure of unstructured socio-cultural environment - it 'scatters' on 'momentary snapshots', as Z. Bauman puts it (2002). In contrast, the pronounced tolerance of uncertainty and ambiguity may indicate the attainment of individual maturity, constancy and integrity of the self, which is able to manage separational and anaclitic anxieties.

In contemporary situation of wide-spread socio-cultural uncertainty clinical psychology is hard up for new methodological approaches that allow developing new technologies of diagnostics and socio-psychological rehabilitation of patients that suffer from personality disorders, are resistant to any kinds of pharmaco- and psychotherapy, are prone to early desocialization and invalidization in new and unconventional life circumstances, which are characterized by the high scale of ambiguity and lack of given rules. As it appears to us, the qualitative characteristics of subjective uncertainty, which are modeled in experimental diagnostic situation, can be considered as ecolgically valid and modeling complex socio-psychological situations in real contemporary life. The ways of managing uncertainty (with the help of which strategies and individual styles the person transforms the chaos of uncertainty into a structured, meaningful whole) serve as the reliable markers to measure stability of the self, productivity of means of self-control and self-regula- 
tion, cognitive realism, socialibility and moral maturity, as well as the markers of their malfunction in mental diseases and personality disorders (Sokolova, 1989, 2005, 2009, 2011).

Here we again encounter the necessity to consider such fundamental problems of psychology as correlation of situational variability and aptitude for development and structural stability of personality, environmental socio-cultural influences and freedom of individual self-determination. All this compels us to turn once more to the methodological traditions, founded by A.R. Luria, B.W. Zeigarnik and S.Ya. Rubinstein, to interpret in new context practical tasks of pathopsychological examination and ecological resources of traditional research paradigms (Zeigarnik, 2000; Rubinstein, 1970).

For Russian pathopsychology, the initially unquestionable priority in diagnostics have been the qualitative analysis and the interpretation of the process of task performance in several contexts: (a) in terms of structural-activity approach; (b) in inseparable connection with the specifics of patient-experimenter communication; (c) considering anamnesis, clinical history and individual social situation of development. Thus it may be said that the best traditions of pathopsychological examination is always the analysis of integral case-study, the realization of unity of ideographic and nomothetic, actual-genetic and historical methodological principles. The communicative aspect of diagnostics appears in the specific organization of research situation and its motivation; in tracing the influence of differential forms of help, approval, critics, training for the process, the structure and the productivity of cognitive activity, in the estimation of anamnesis and actual sustaining resource of patient's social situation out of the hospital. The ability to develop the strategies and the tactics of pathopsychological experimentation on the basis of knowing general regularities of clinical picture and with regard to patient's individuality is considered the essential and the most difficult professional skill in Russian pathopsychology, which is necessary for the valid pathopsychological conclusion and elaboration of practical recommendations (Rubinstein, 1970). In postulation and upholding the principles of activity, subjectivity, communicative mediation in respect to the tasks of psychodiagnostics, the practical pathopsychology had greatly outpaced the psychological theory: it was in the mainstream of the humanistic ideas of 1960-1970-ies with their acute interest to axiological and semantic 'dimensions' of personality, to integrity and value of human relations that mediate (in norm and in pathology) the structure and the dynamics of cognitive activity, the malfunction of which cannot be understood without notice of its motivational, semantic and relational components (Zeigarnik, 2000).

The set of pathopsychological methods is commonly accepted and became a kind of a standard. Here a lot of methodical and methodological questions appear, which call for further discussion and scientific reflection. For example, may one consider the methods, which are used for the diagnostics of structure of the cognitive processes, in the viewpoint of the projective paradigm, i.e. as the methods for the diagnostics of personality structure and personal organization? May one put these methods on the basis of the scientific criteria into the class of the projective ones or at least rate as those having a projective component? If "yes", than does one need some modifications of the procedure of their usage and the very organization 
of pathopsychological examination, its setting? We hold the affirmative answer to these questions and here are the reasons why.

It is commonly known that the projective methods are those that are directed on modeling various aspects of experiencing uncertainty, which is created by informational, sensory, emotional or semantic deficit. The conditions that provide modeling the experiences of uncertainty (and at the same time the experimental methods of its creation) are the specific organization of the whole situation of projective examination (stimulus material, its presentation, motivational instruction) and the specifics of the dyadic relationships "subject-psychologist", which are exteriorated and formed in the process of the whole examination. The multidimentionality of deprivation intensifies the load upon the ability of a person to bear uncertainty without loss of orientation in reality, without disintegration of personality, without self-destruction and destruction of the purposeful interaction with the physical, the social and the interpersonal environment. The uncertain situation provokes the emotional states of anxiety and activates the steady system of defensive and coping strategies of self-regulation and representations of the Self and the Other. The uncertainty of interpersonal relationships with the diagnostician is achieved through some ambiguity of his/ her communicative position: the combination of benevolently-neutral attitude and frustrating avoidance of direct answers to patient's questions. This lets the patient to 'encounter' his/ her own experience of uncertainty, which reconstructs the chaos of affective states and anxiety, the early traumatic experience of emotional relations with significant others, the world of infantile fears, conflicts and defenses. Thus, the projective potential of uncertainty calls forth the metacommunicative, the symbolic stratum of communication from the earlier experiences of relationships that calk the unconscious schemes of transference and countertransference. But the ambiguity of experimental situation also gives the unique chance to 'encounter' the here and now developing relationship of collaboration between patient and psychologist. Our research shows that the substantial specifics of emotional experiences, the ways of their structuring and control, the qualitative and stylistic characteristics of cognitive activity in conditions of 'tolerance-intolerance' of uncertainty are the strong criteria of the diagnostic appraisal of borderline and narcissistic structural and functional personality organization.

In comparison with projective methods, classical pathopsychological examination is organized a little bit differently: as a rule, the diagnostician works "inside" the so-called expert motivation, which to a great degree frustrates and narrows the range of individual motivation that forms for a patient the real sense of executed diagnostic tasks and personal interested involvement. In this sense we find it not quite justified in a traditional set of pathopsychological methods to introduce personality questionnaires and much less projective techniques without change of setting: i.e. without differentiation of diagnostic tasks, motivation and time of examination, of instruction and dynamics of development of relationships between the diagnostician and the subject.

However, serious differences in methodology do not prevent us from taking a good look at projective possibilities, contained in traditional pathopsychological procedures, given that the organization of examination will be modified. Notably, each of the proposed tasks-tests contains the element of choice from a 
big quantity of solutions, and thus each test is created in such a manner that the choice of the optimal solution is hampered by perceptive, semantic or conceptual redundancy of conditions, mixed with the 'background noise' of false, inaccurate or random choices. For example, the completion of the method Classification of Objects involves abstracting from an array of inessential, emotionally charged or concretely-situational criteria; the same is true for the method Exclusion of Objects. The subject faces the need to concentrate attention and hold it durably on the goal of the task, which demands tuning out from the field (from objective and social environment), as well as the choice that rests not only upon the ability of analytic and synthetic activity, but also upon energies, self-dependence, criticism, reflection, resistance of self-esteem to frustration, that influence not less the ultimate outcome of task performance. From our point of view, the situation of the pathopsychological tests can be interpreted analogically with the well-known experimental situations of evaluation of individual differences and cognitive style, when uncertainty of conditions lets showing up individual predispositions (passive following the exterior circumstances or resistance to field forces and resting upon inner system of norms). The individual choice of strategy is dictated simultaneously by the demands of current problem specifications (real circumstances) and by the system of stable personal preferences concerning self-esteem, notions about significant others, values and / or necessity of tuning out from them, which provokes projection of the integral constellation of cognitive, emotional-regulative and communicative strategies of personality, its life-style. This methodological perspective is a further development of the ideas of A.R. Luria and B.W. Zeigarnik concerning the systemic organization of higher psychic functions and its restructuring under the conditions of psychopathology into a new configuration, a new Geschtalt. This allowed many Russian pathopsychologists to realize in specific investigations the principle of personality analysis "through cognitive processes" and "personal component of mental activity" of the patient (V.V. Nikolaeva, S.N. Loginova, I.I. Kozhuhovskaya, L.V. Bondareva, T.I. Tepenizina, E.T. Sokolova et al.).

Today we may say that clinical psychology is becoming subjective and ecological, inasmuch as it takes into account socio-cultural and environmental factors, which take part in generation and sustenance of anomalous development of personality. The last is evident for borderline and narcissistic personality pathology, which is characterized by hypertrophied and paradoxical 'leaps' between poles of dependency-autonomy from social environment and by deficit of individuality combined with pronounced individualism. We also get increasingly aware of the limitations of ecological validity of results, which are received exclusively on the basis of quantitative estimation of testing procedures, in 'sterile' laboratory conditions, with distance diagnostics; we become more convinced in the necessity to interpret the results of examination in communicative context, taking into account the relationships of a patient, which are built in the process of interaction during an examination as well as in an out-of-hospital situation. The support and the frustration that come from social networks and family, the educational degree and the fulfilling job, the communicative resource and the quality of compliance (as well 
as the clinical and individual characteristics of the patient) - are extremely essential factors of symptom-building, disability, spontaneous remission, effectiveness of psychotherapy.

To resume the discussion of the problem, which was set up in the given article, we will stress some important moments once more. "The psychology," wrote A.R. Luria, "certainly cannot extract, isolate personality from the flow of social evolution and social influences, otherwise it risks to end in a fiasco in every attempt to grasp many contents and forms of the mental life" (A.R. Luria, 2003b, p. 319). We will add that psychology, which 'dissolves' personality in social contexts also risks ending in a fiasco by 'losing' personality.

It is also important to stress the many-valuedness and the versatility of the phenomenon of subjective uncertainty, as well as the meaning of socio-cultural, individual, personal and clinical factors that determine the specifics of its experience, the ambiguity of its social and political appraisal. The lack of predictability and the risk is definitely inherent in the state of uncertainty, but it would be a big logical mistake and a contradiction to the common sense to reduce its consequences to the imminence of personal madness or a social-political catastrophe. The history knows that the radical ways of ultimate solution of the 'intolerance of uncertainty' problem may be dictatorship, totalitarianism and the cruelest control of social and personal life (Adorno et al. 1950; Arendt 2008), and these ways are sufficiently reflected in philosophy and sociology. This problem appeals Russian clinical psychology in the context of correlation of socio-cultural and individually personal determination of activity's self-regulation, of the social and the individual, the stable and the developing in self-identity. The substantial and the methodological problematization of subjective intolerance of uncertainty, the profound consideration of various facets of this phenomenon as a cultural fact and its role in etiogenesis and pathogenesis of personality disorders sets new perspectives of development of cultural-historical approach to analysis of pathologic and 'borderline' phenomena is contemporary socio-cultural context.

\section{References}

Adorno, T. W., Frenkel-Brunswik, E., Levinson, D. J., \& Sanford, R. N. (1950). The authoritarian personality. New York: Harper and Row.

Arendt, H. (2008). Banalnost zla. Eihman v Ierusalime [Banality of Evil. Eichmann in Jerusalem]. Moscow: Evropa.

Auerbach, J., Blatt, S.J. (1996). Self-representation in severe psychopathology: The role of reflexive self-awareness. Psychoanalytic psychology, 13, 297-341. doi: 10.1037/h0079659

Bauman, Z. (2002). Individualizirovannoe obschestvo. [The individualized society]. Moscow: Logos.

Beck, U. (2000). Obschestvo riska. Na puti $k$ drugomu modernu [Risk society. Towards a new modernity]. Moscow: Progress-Tradiciya.

Belinskaya, E.P. (2007). Neopredelennost kak subjektivnoe perezhivanie radikalnyh socialnyh izmeneniy [Uncertainty as subjective experience of radical social changes]. In Socialnaya psihologiya: Aktualnye problemy issledovaniy [Social psychology: Current issues of research] (pp. 43-62). Eds. E.P. Belinskaya, T.P. Emelyanova. Moscow: Vygotsky Fund. 
Belinskaya, E.P. (2009). Sovladanie kak socialno-psihologicheskaya problema [Coping as socialpsychological problem]. Psihologicheskie issledovaniya [Psychological Studies], 1 (3). Retrieved from http://psystudy.ru.

Blatt, S.J., Lerner, H.D. (1983). The psychological assessment of object representation. Journal of Personality Assessment, 47, 7-28. doi: 10.1207/s15327752jpa4701_2

Bruner, J., Oliver, R., Greenfield, P. (Eds.) (1971). Issledovanie razvitiya poznavatelnoj deyatelnosty [Studies in cognitive growth]. Moscow: Pedagogika.

Epstein, M. (2011). O Rossii s nadezhdoj [On Russia with hope]. Novaya gazeta [New newspaper], 135, 15-16.

Hogg, M. A. (2007). Uncertainty-identity theory. In M. P. Zanna (Ed.), Advances in experimental social psychology, 39, 70-126. San Diego, CA: Academic Press.

Holodnaya, M.A. (1998). Kognitivnye stili: paradigma "drugih" intellektualnyh sposobnostej. [Cognitive styles: A paradigm of "different" intellectual abilities]. Stil cheloveka: Psihologicheskij analis [Human style: Psychological analysis] (pp. 52-63) Ed. by A.V. Libin. Moscow: Smysl.

Kornilova, T.V. (2010) Princip neopredelennosti v psihologii: osnovaniya i problemy [The uncertainty principle in psychology: foundations and challenges] Psikhologicheskie Issledovaniya [Psychological Studies], 3(11). Retrieved from http://psystudy.ru

Luria, A.R. (2001). Etapy projdennogo puti. Nauchnaya biografiya [The milestones of the road passed. Scientific autobiography]. Ed. by E.D. Homskaya. Moscow: Akademiya.

Luria, A.R. (2003a). Objectivnoe issledovanie dinamiki semanticheskih system [Objective study of dynamics of semantic systems]. In A.R. Luria, Psihologicheskoe nasledie. Izbrannye trudy po obschej psihologii [Psychological heritage. Selected works on general psychology]. Eds. Zh.M. Glozman, D.A. Leontiev, E.G. Radkovskaya (pp. 211-235). Moscow: Smysl.

Luria, A.R. (2003b). Principy realnoj psihologii (o nekotoryh tendenciyah sovremennoj psihologii). [Principles of realistic psychology (on some tendencies of contemporary psychology)]. Psihologicheskoe nasledie. Izbrannye trudy po obschej psihologii [Psychological heritage. Selected works on general psychology] (pp. 295-383). Eds. Zh.M. Glozman, D.A. Leontiev, E.G. Radkovskaya. Moscow: Smysl.

Rotenberg, E.T. (1971). Vliyanie narushenij lichnostnogo komponenta deyatelnosti na process vospriyatiya [Influence of personal component of activity disorders on perceptive process] (PhD thesis). Moscow: MSU.

Rubinstein, S.Ja. (1970). Experimentalnye metodiki patopsihologii i opyt ih primeneniya $v$ klinike [Experimental methods of pathopsychology and experience of their application in clinics]. Moscow: Medicina.

Sokolova, E.T. (1976). Motivaciya $i$ vospriyatie v norme i patologii [Normal and pathological motivation and perception]. Moscow: MSU.

Sokolova, E.T. (1980). Proyektivnye metody issledovaniya lichnosti [Projective methods of personality research]. Moscow: MSU.

Sokolova, E.T. (1989). Samosoznanie i samoocenka pri anomaliyah lichnosti [Self-consciousness and self-esteem in abnormalities of personality]. Moscow: MSU.

Sokolova, E.T. (2005). Perenosimost-neperenosimost neopredelennosti: socio-kulturnye, differencialno-psihologicheskie, klinicheskie aspekty [Tolerance and intolerance of uncertainty: socio-cultural, differencial-psychological and clinical aspects]. Ezhegodnik rossiyskogo psihologicheskogo obschestva [Russian psychological society yearbook] (pp. 422-423). Moscow: RPO.

Sokolova, E.T. (2009) Narcissism kak klinicheskij i socio-kulturnyj fenomen. [Narcissism as a clinical and socio-cultural phenomenon. Voprosy psihologii [Psychology Issues], 1, 67-80. 
Sokolova, E.T. (2011) Affectivno-kognitivnaya differencirovannost / integrirovannost kak dispozicionnyj factor lichnostno-povedenceskih rasstrojstv. [Affective-cognitive differentiation / integrity as a dispositional factor of personality and behavioral disorders]. Teoriya razvitiya: Differencionno-integracionnaya paradigma [Developmental theory: A differential-integral paradigm]. Ed. N.I. Chuprikova. Moscow: Jazyki slavyanskih kultur.

Vygotsky, L.S. (1982). Sobranie sochinenij [Collected writings], Vol. 1. Moscow: Pedagogika.

Witkin, H.A., Lewis, H.B., Hertzman, M., Machover, K., Meissner, P. B., \& Wapner, S. (1954). Personality through perception: An experimental and clinical study. New York: Harper \& Brothers.

Witkin, H. A., Goodenough D. R. (1981). Cognitive styles-essence and orgins: Field dependence and field independence. New York: International Universities.

Zeigarnik, B.W. (2000). Patopsihologiya [Pathopsychology]. Moscow: Aprel.

Zinchenko, V.P. (2007) Tolerantnost k neopredelennosti: novost ili psihologicheskaya tradiciya? [Tolerance for ambiguity: news or psychological tradition?]. Voprosy psihologii [Psychology Issues], 6, 3-20. 